International Journal of Heritage, Tourism and Hospitality Vol. (12), No. (3/2)

Special issue on papers of the $11^{\text {th }}$ ICTH (2018) organized by Faculty of Tourism and Hotels,

Fayoum University

\title{
Antecedents and Consequences of Food Quality in Egyptian Healthcare
}

Karam Zaki Mohamed Ahmed

Faculty of Tourism and Hotels, Fayoum University

\section{Abstract}

This research examined food production/service quality mediating effect in the relationship between the innovative human resource management practices (IHRMPs) and patient satisfaction in Egyptian healthcare. Case study strategy applied in two Egyptian hospitals. Structural equation modelling (SEM) was used. A convenient sample included 252 hospital patients and 108 kitchen staff was selected. Findings indicated a strong positive IHRMP effects on patient satisfaction. According to SEM analysis, food service quality factor was fully mediated the direct relationship between IHRMPs and the patient satisfaction. While food production quality factor was not mediated the relationship between IHRMPs and patient satisfaction. The article identifies opportunities to use comprehensive IHRMPs effectively and to develop other food quality indicators that may affect patient satisfaction. This article is among the few studies offering a framework to identify service quality mediation effect in the relationship between IHRMPs and patient satisfaction in Egyptian healthcare. This framework is based on social exchange theory in which quality knowledge perceptions in hospitals could come from IHRMPs, which consequently promotes patient satisfaction.

Keywords Quality, Patient satisfaction, Social exchange theory, Healthcare, Egypt

\section{Introduction}

The largest healthcare component is human resources (Nayeri et al., 2005). Healthcare depends on the human resources as it is labour intensive, which has posed particular challenges for ensuring patient satisfaction and business outcomes. Indeed, a great challenge faces Arab countries, especially Egypt, is to provide sufficient human resources to deliver high-quality services (Budhwar and Mellahi, 2007).

Patient satisfaction is considered a key performance indicator in healthcare business (Ahmed et al., 2015). Many scholars highlighted the relationship between human resource management (HRM) practices and healthcare food production/service quality (Haynes and Fryer, 2000; Amin et al., 2017). However, research related to HRM practices and its relationship to patient satisfaction is not sufficient (Pulce, 2003; Huang, 2017). In addition, the food production/service quality mediating effect in the relationship between Innovative Human Resource Management Practices (IHRMPs) and patient satisfaction in the Egyptian healthcare sector still needs more investigation. Moreover, the healthcare literature has not presented a comprehensive IHRMPs overview, which affects food production/service quality to ensure satisfied patients (Cho et al., 2006; Bhanugopan et al., 2013). Accordingly, we explored patient satisfaction with food production/services and measured kitchen staff perspectives on IHRMPs to elucidate the relationship between these factors.

\section{Literature review \\ Healthcare in Egypt}

Healthcare managers are forced to find innovative tools to remain competitive and to provide patients with satisfactory services (Sargeant, 2010). Healthcare managers look for potential in their performance to achieve their goals (Aiello et al., 2010). The healthcare system in Egypt is complex with many entities and bodies involved in management hierarchy, financing and care provision (WHO, 2010; Farahat et al., 2018). In Egypt, healthcare is delivered through different systems, including private, public or governmental and university hospitals (Mostafa, 2005). 


\section{Healthcare Ihrmps}

According to Som (2008), IHRMPs are completely different than the traditional HRM practices. Wolfe (1995) defined IHRMPs as new ideas and practices that best manage individuals. These practices are similar to administrative innovation because IHRMPs achieves firm effectiveness (Agarwala, 2003). According to Nickson's (2007) HRM cycle, IHRMPs include three layers: first, practices attracting an effective workplace (e.g., recruitment and selection); second, those maintaining an effective workplace (e.g., rewards); third, developing an effective daily workplace (e.g., training). We argued that IHRMPs (e.g., recruitment and selection; training and development; performance appraisal; internal communication; rewards and benefits; diversity) could affect patient satisfaction.

It is considered that IHRMPs are a critical process for achieving effective hospital food production or service (El-Jardali et al., 2009; Amin et al., 2017). Puckett (2004) declared that healthcare staff skills ensure catering department success. Nevertheless, a poor image related to staff recruitment in the hospitality industry generally and healthcare particularly, is common (Nickson, 2007). Furthermore, the internal working environment and recruitment practices are considered questionable in many hospitals (El-Jardali et al., 2009). It is reported that IHRMPs help hospitals to maintain a high service quality; increase satisfaction; decrease staff turnover; boost productivity and performance; meet patient expectations (Kloutsiniotis and Mihail, 2017). The IHRMPs are a critical practices that affected food production and service in many hospitals (Wickramasinghe, 2015).

According to Siddiqui and Kleiner (1998), recruitment and selection practices aimed to develop a workplace by having the right individuals to achieve hospital purposes. However, selecting suitable employees is challenging (Severt et al., 2008). There are many issues reported by Davis et al., (2013) that affect the recruitment and selection process, including hospital's catering strategy; menu layout; food production or service operation. There are two recruitment methods: first, attracting qualified staff from inside; second, external recruitment from outside (Kim et al., 2006).

Healthcare staff training plays a vital role in improving their skills which will reduce turnover ratios afterward. Training will boost staff motivation and commitment (Delery and Gupta, 2016). Training programmes involve: on-the-job training provided for staff in their workplace; and off-the-job training, which performed outside the workplace (Pulce, 2003).

Performance appraisal is a systematic evaluation of staff work behaviour and attitudes related to the job criteria. Based on the accurate job criteria and job behaviour measurement, job responsibilities and requirements are easy to perform (Siddiqui and Kleiner,1998). Managers should develop accurate employee appraisal criteria based on the organization's mission (McEvoy and Buller, 2013).

Ulrich (1997) indicated many internal communication types available in any organization, such as staff understanding and accepting the top management messages, positive information-sharing between departments, devoted time for problem-solving and employees' existence to give suggestions to management.

Compensation and organizational outcomes are closely related to each other as concluded by Koss (2008). Tropman (2002) differentiated between old and new pay as similar to the compensation word that compensates staff for their done work. Since linking pay to employee success and the firm is the main concern of new pay, Old pay winds up being a frozen system based on entitlement and internal equity. Bloom and Milkovich (1998) declared that pay level could be a critical factor when it comes to attracting applicants and it could be an employee effort indicator. Compensation is related to individual attitudes such as job satisfaction. When incentives applied correctly, it ensures service quality, but if used randomly it could result in lower desired outcomes. In general, satisfaction and work improvement have been associated with compensation (Koss, 2008). 
Two decades ago, there has been a global trend in the healthcare literature to stress on workforce diversity by hiring women and other minorities (Ulrich,1997). Equal employment opportunities are one of the main diversity practices (Morrison,1992).

\section{Food production quality in healthcare}

Food production is of high quality when includes preparing and cooking perfectly the right food quantity and quality. According to Cardello et al., (1996) food production and service quality in healthcare is a vital part of the medical treatment which contributes to the patient' nutritional needs and then achieving patient satisfaction. Hwang et al., (2003) reported that food production quality plays an important role in patient satisfaction. However, the patient expectation of hospital food service is reported to be of a bad quality (Hartwell et al., 2006). Ahmed et al., (2015) highlighted that food production in hospitals is complicated, there are many issues affect cooking method, such as; menu, equipment, staff, and kitchen space (Rodgers, 2005). Puckett (2004) counted four types of food production systems used in hospitals such as: cook-serve; cook-chill; cook-freeze; sous-vide; ready meal. Assaf et al., (2008) explained that standard recipes provide information about menu items. Davis et al., (2013) added that portion size is essential in pricing menu items. Hospital food production/service requires co-operation between all hospital staff. Food production staff should be trained to have knowledge about food production/service operation (Hartwell et al., 2006). Food quality indicators are: taste; texture; color; presentation; menu variety; temperature; staff attitude (Wright et al., 2006).

\section{Food service quality in healthcare}

It is recognized that healthcare is one of the biggest food production /service providers with a limited budget. It needs to survive in a competitive environment. The patient experience is a key performance indicator of quality and often reflected by the cooked food quality. Therefore, it is compulsory to satisfy the patient needs/expectations (Namkung and Jang, 2007). Menu and staff attitude also influence patient satisfaction (Porter and Cant, 2009). Food quality is difficult to measure because it depends on patient expectations and perceptions (Hartwell et al., 2006). Wright et al., (2006) confirmed that food quality is characterized by taste; texture; colour; flavour; presentation; temperature; staff attitude. However, Namkung and Jang (2007) were depended on six quality indicators: presentation; variety; healthy options; taste; freshness; temperature. Edwards et al., (2000) confirmed that meal quality depends on food materials, patient and the situation under which the food is consumed. Food has a major impact in terms of how a patient recovers, and just how long they have to stay in a hospital (Hartwell et al., 2006; Fatima et al., 2018).

\section{Patient satisfaction}

One of the key performance indicators for hospital food production quality is the patient satisfaction (Sahin et al., 2006). Patient satisfaction is defined as the emotional reaction to the perceived quality of healthcare service during the stay (Smith et al., 2004). It is a critical success indicator that helped hospitals achieve best practice by offering high service quality with reduced cost (GonzálezValentín et al., 2005). Owing to high competition among hospitals, it is highly focused on quality improvements to meet patient needs. Patient satisfaction is considered an important service output. Therefore, understanding patient perceptions are necessary to remain competitive (Fatima et al., 2018). However, the negative image of hospital nutrition is common because many patient expectations are undesirable about food and service quality (Hartwell et al., 2006). Food production and service quality are considered the most significant factor affects patient satisfaction. Patient feedback is required for the management to determine strengths and weaknesses points within the food production/service system (Wright et al., 2006; Farahat et al., 2018). 
International Journal of Heritage, Tourism and Hospitality Vol. (12), No. (3/2)

Special issue on papers of the $11^{\text {th }}$ ICTH (2018) organized by Faculty of Tourism and Hotels,

Fayoum University

Conceptual framework and hypotheses development

Figure 1: Antecedents and consequences of food production/service quality conceptual framework.
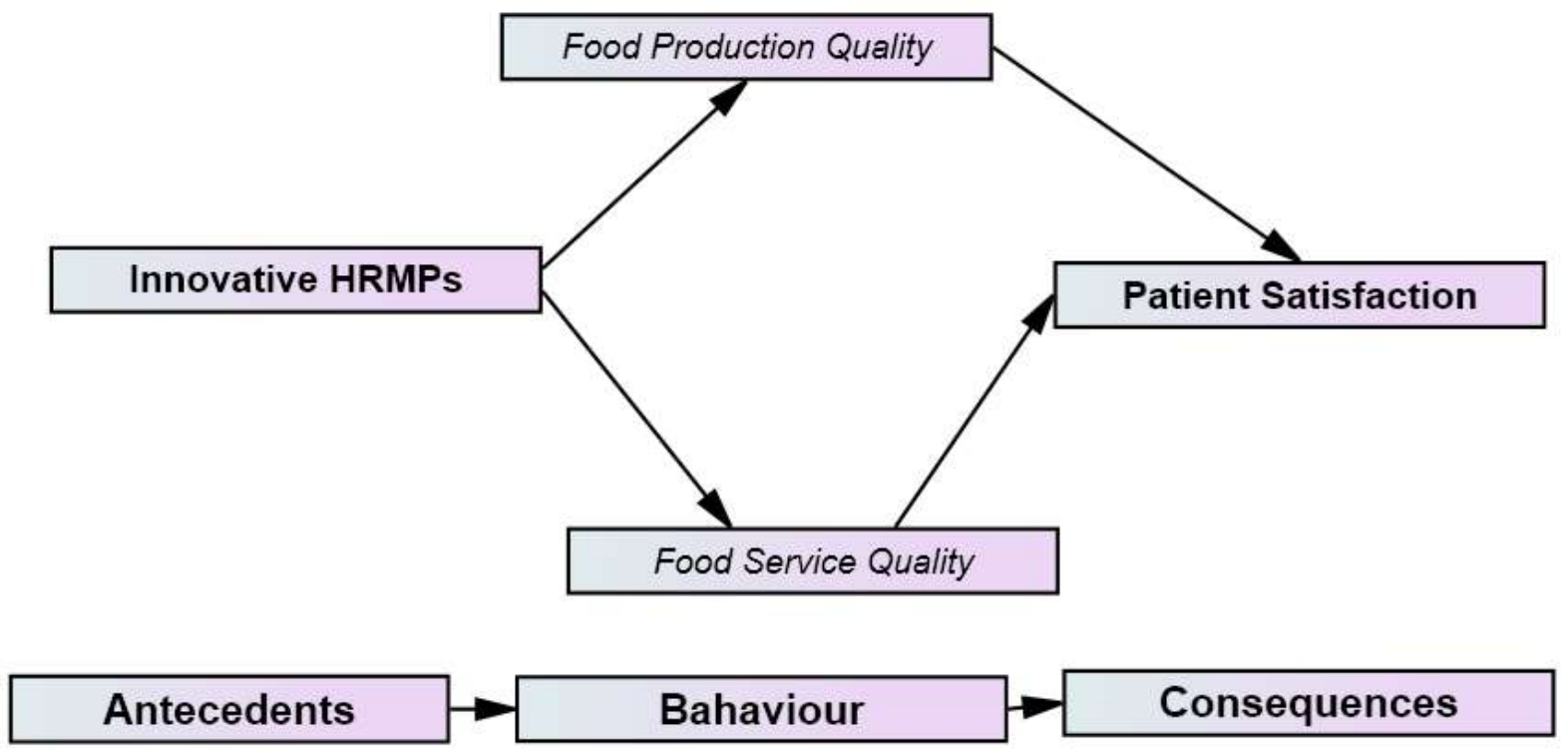

Source: modified from (Pulce ,2003; Purcell et al., 2007; Kakuma et al., 2011; Wickramasinghe, 2015; Farahat et al. , 2018; Fatima et al., 2018 )

The research framework theoretical foundations were based on the social exchange theory of Blau (1964) that used to understand how healthcare staff achieves their job tasks well using IHRMPs and then getting a value to their organization such as patient satisfaction. We argued that healthcare staff behaviour on delivering high food production/service quality is resulted from using proper IHRMPs and will consequently ensure patient satisfaction.

The basic justification behind this research is that healthcare satisfied patient does not come in a sudden from IHRMPs without the mediating effect of food production/service quality, as recommended by Kloutsiniotis and Mihail (2017). It has been argued that in healthcare, quality improvement must depend on sound staffing, training, and other HRM practices (Purcell et al., 2007). Kloutsiniotis and Mihail (2017) highlighted benefits gained from implementing IHRMPs in healthcare, such as getting outstanding service and patient satisfaction.

Previous HRM literature indicated that employees should receive sufficient training to deliver high service quality. Many scholars addressed the positive relationship between employee's perceptions of HRM practices and patients' ratings of service quality in healthcare (Kakuma et al., 2011; Wickramasinghe, 2015). Pulce (2003) examined the relationship between IHRMPs and patient satisfaction. Scotti et al., (2007) confirmed the relationship between IHRMPs and service quality. However, little research attempts have been done to discover the mediating effect of food production/service quality on the relationship between IHRMPs and patient satisfaction. This research hoped to bridge this gap because these relationships (see Figure 1) were not empirically tested in Egyptian healthcare yet. These previous explanations guided us to test the following hypotheses:

H1. IHRMPs will positively affect food production quality.

H1. IHRMPs will positively affect food service quality.

H3. Food service quality is mediating the relationship between IHRMPs and patient satisfaction.

H4. Food service quality is mediating the relationship between IHRMPs and patient satisfaction.

H5. IHRMPs will positively affect patient satisfaction. 


\section{Methodology}

The case study was applied to investigate the patient satisfaction with food production/services quality and kitchen/ service staff perspectives on IHRMPs in a public hospital (Kasr Al-Ainy) and a private hospital (Dar Al-Fouad) in Egypt.

Case 1-QSR: was established in 1937, it provides their facilities through six hospitals located in Cairo university are: Al Manial University Hospital (1794 beds); Gynaecology Diseases and Delivery Hospital (297 beds); Internal Medicine Diseases Hospital (306 beds); New University Children Hospital (185 beds); New Kasr Al-Ainy Teaching Hospital (1200 beds); about 750,000 patients received clinical service annually (Saleem et al., 2009). Case 2-DAR: was established in 1996, it became the most popular hospital, because of delivering a high standard of healthcare service in Egypt. DAR was designed to offer the best clinical outcome, as well as putting the patient requirements and their needs first. It offers some facilities to their patient and visitors such as; accommodations, food and beverage behind the clinical service. It has 168 beds; each bedroom is furnished to a high standard of comfort for the patient. All rooms have comfortable furniture and pleasant views (Ghali, 2009).

Case 1 was chosen as it is one of the biggest and oldest medical hospitals not only in Egypt but also in Africa and the Middle East. While case 2 was selected as it delivers a unique healthcare in the Egyptian private-sector hospitals and due to its well-known reputation. Using two different samples is to increase results external validity and to enrich the research implications. Permission was given for the researchers to have a look at the ward and asked patients to fill out the questionnaire.

\section{Data collection}

To test the research hypotheses, a questionnaire technique was used with two different respondents (patient and kitchen/service staff) constituting the main population. To collect the main data, we employed two survey versions based on a convenient sample method type. The first version was written in Arabic language and then translated into English. Piloting was conducted among 50 patients and kitchen staff to ensure the initial survey reliability and to explore any potential misunderstanding among respondents related to the items wording or survey length. Participation was completely voluntary. A total of 200 questionnaires were distributed in case 1 and 250 questionnaires were distributed in case 2. The final sample size of 360 usable questionnaires was finally returned with $80 \%$ response rate (Table 1) in which the staff questionnaires were 108 and patient questionnaire were about 252.Data collection was performed from 21 May 2017 to 20 July 2017.

Table 1: Sample and response rate

\begin{tabular}{|c|c|c|c|c|c|c|}
\hline Category & $\begin{array}{c}\text { Questionnaires } \\
\text { distributed }\end{array}$ & \multirow{2}{*}{\multicolumn{2}{|c|}{$\begin{array}{c}\text { Returned } \\
\text { Questionnaires }\end{array}$}} & $\begin{array}{l}\text { Response } \\
\text { Rate }(\%)\end{array}$ & $\begin{array}{c}\text { Final } \\
\text { sample size }\end{array}$ & $\begin{array}{c}\text { Final response } \\
\text { Rate }(\%)\end{array}$ \\
\hline & & & & \multirow{2}{*}{$88 \%$} & \multirow{4}{*}{360} & \multirow[t]{4}{*}{$80 \%$} \\
\hline Case 1: QSR & 200 & $\begin{array}{c}26 \\
\text { Staff }\end{array}$ & $\begin{array}{c}149 \\
\text { Patients }\end{array}$ & & & \\
\hline & & \multicolumn{2}{|c|}{185} & \multirow[t]{2}{*}{$\% 74$} & & \\
\hline Case 2: DAR & 250 & $\begin{array}{c}82 \\
\text { Staff }\end{array}$ & $\begin{array}{c}103 \\
\text { Patients }\end{array}$ & & & \\
\hline
\end{tabular}

\section{Measurement}

The used measures of the conceptual framework were developed and validated from previous literature (Table 2). The framework variables were measured using Five-point Likert scale starting from $1=$ strongly disagree to $5=$ strongly agree for all the questionnaire factors except the perceived 
International Journal of Heritage, Tourism and Hospitality Vol. (12), No. (3/2)

Special issue on papers of the $11^{\text {th }}$ ICTH (2018) organized by Faculty of Tourism and Hotels,

Fayoum University

food production quality factor in which a scale developed from $1=$ never, $3=$ sometimes to $5=$ always. The measurement model contained overall 67 items (24 items of IHRMPs and 12 items for food production quality indicators perceived by staff) while, the patient questionnaire included 5 items for food production quality indicators, 20 items for the perceived food service quality and 6 items for patient satisfaction) which are adequate for conducting path analysis using the Structural Equation Modelling (SEM).

\section{Data analysis}

The descriptive analysis, reliability and validity were analysed using SPSS-24 to highlight the main characteristics of the sample and the demographic data.

Table 2: Questionnaire items measurement operationalization

\begin{tabular}{|c|c|c|c|c|}
\hline Constructs & Validated by & \multicolumn{2}{|c|}{ Scale dimensions } & Sample of items \\
\hline \multicolumn{5}{|c|}{ Kitchen Staff Questionnaire } \\
\hline \multirow[t]{6}{*}{ IHRMPs } & (Chew, 2004) & \multicolumn{2}{|c|}{$\begin{array}{c}\text { Recruitment and } \\
\text { selection }\end{array}$} & $\begin{array}{c}\text { My hospital conducts structured and } \\
\text { standardized interviews (as opposed to } \\
\text { unstructured interviews) for selection of } \\
\text { jobs. }\end{array}$ \\
\hline & $\begin{array}{l}\text { (Tsaur and } \\
\text { Lin, 2004) }\end{array}$ & \multicolumn{2}{|c|}{$\begin{array}{l}\text { Training and } \\
\text { development }\end{array}$} & $\begin{array}{l}\text { My hospital conducts systematic } \\
\text { analysis to determine the needs for } \\
\text { training programs. }\end{array}$ \\
\hline & $\begin{array}{l}\text { (Tsaur and } \\
\text { Lin, 2004) }\end{array}$ & \multicolumn{2}{|c|}{$\begin{array}{l}\text { Performance } \\
\text { appraisal }\end{array}$} & $\begin{array}{l}\text { My hospital emphasizes job-relevant } \\
\text { criteria in the appraisal systems. }\end{array}$ \\
\hline & (Ulrich, 1997) & \multicolumn{2}{|c|}{$\begin{array}{c}\text { Internal } \\
\text { communication }\end{array}$} & $\begin{array}{c}\text { This hospital keeps staff well-informed } \\
\text { on daily issues. }\end{array}$ \\
\hline & (Chew, 2004) & \multicolumn{2}{|c|}{$\begin{array}{l}\text { Rewards and } \\
\text { Benefits }\end{array}$} & This hospital pays well. \\
\hline & (Ulrich, 1997) & \multicolumn{2}{|c|}{ Diversity } & $\begin{array}{l}\text { This hospital encourages experience } \\
\text { rather than seniority. }\end{array}$ \\
\hline $\begin{array}{l}\text { Perceived Food } \\
\text { production } \\
\text { quality by staff }\end{array}$ & \multicolumn{3}{|c|}{ (Hartwell et al., 2006) } & $\begin{array}{l}\text { How often have quality policies for food } \\
\text { production? }\end{array}$ \\
\hline \multicolumn{5}{|c|}{ Patient Questionnaire } \\
\hline $\begin{array}{l}\text { Perceived Food } \\
\text { production quality } \\
\text { by patients }\end{array}$ & $\begin{array}{l}\text { (Wright } \\
\text { et al., } \\
\text { 2006) }\end{array}$ & $\begin{array}{l}\text { Sensory } \\
\text { aspects of } \\
\text { quality }\end{array}$ & & The food tastes good. \\
\hline \multirow[t]{5}{*}{$\begin{array}{l}\text { Food service } \\
\text { quality }\end{array}$} & \multirow{5}{*}{$\begin{array}{l}\text { (Gazzoli } \\
\text { et al., } \\
2010)\end{array}$} & Attitude & \multicolumn{2}{|c|}{$\begin{array}{c}\text { You can count on this hospital service employee } \\
\text { being friendly. }\end{array}$} \\
\hline & & Behaviour & \multicolumn{2}{|c|}{$\begin{array}{l}\text { This service employee responds quickly to my } \\
\text { needs. }\end{array}$} \\
\hline & & Expertise & \multicolumn{2}{|c|}{$\begin{array}{l}\text { This service employee is able to answer my } \\
\text { questions quickly. }\end{array}$} \\
\hline & & Waiting time & \multicolumn{2}{|c|}{$\begin{array}{l}\text { This service employee tries to keep my waiting } \\
\text { time to a minimum. }\end{array}$} \\
\hline & & Tangibles & \multicolumn{2}{|c|}{$\begin{array}{l}\text { I am pleased with the whole service provided at } \\
\text { this hospital. }\end{array}$} \\
\hline
\end{tabular}


International Journal of Heritage, Tourism and Hospitality Vol. (12), No. (3/2)

Special issue on papers of the $11^{\text {th }}$ ICTH (2018) organized by Faculty of Tourism and Hotels,

Fayoum University

\begin{tabular}{|c|c|c|c|}
\hline & & Valence & $\begin{array}{c}\text { When I leave this hospital usually I feel had a } \\
\text { good experience. }\end{array}$ \\
\cline { 3 - 4 } & $\begin{array}{c}\text { Overall } \\
\text { quality }\end{array}$ & $\begin{array}{c}\text { I believe that this hospital offers excellent } \\
\text { service. }\end{array}$ \\
\hline $\begin{array}{c}\text { Patient } \\
\text { satisfaction }\end{array}$ & $\begin{array}{c}\text { (Hartwell } \\
\text { et al., } \\
\text { 2006) }\end{array}$ & & I am satisfied with meal presentation. \\
\hline
\end{tabular}

The multivariate analysis was performed in two stages of performing Exploratory Factor Analysis (EFA) and then Confirmatory Factor Analysis (CFA). The measurement and structural models were executed using SEM analysis by AMOS-20. SEM was used to highlight the relationships between the research variable simultaneously (Byrne, 2013).

\section{Results and discussions}

Descriptive analysis

Table (3) indicated sample characteristics. The participated patients were more than the hospital kitchen staff. The majority of the respondents were from males than females.

Table 3: Descriptive statistics ( $\mathrm{N}=360 ; \mathrm{n} 1=252$ patients; $\mathrm{n} 2=108$ staff).

\begin{tabular}{|c|c|c|c|c|c|c|c|c|c|}
\hline \multicolumn{2}{|c|}{ Sample characteristics } & \multicolumn{4}{|c|}{ Frequency } & \multicolumn{4}{|c|}{$(\%)$} \\
\hline \multicolumn{2}{|c|}{ Patients } & \multicolumn{4}{|c|}{252} & \multicolumn{4}{|c|}{70} \\
\hline \multicolumn{2}{|l|}{ Staff } & \multicolumn{4}{|c|}{108} & \multicolumn{4}{|c|}{30} \\
\hline \multicolumn{2}{|l|}{ Chefs } & \multicolumn{4}{|c|}{82} & \multicolumn{4}{|c|}{23} \\
\hline \multicolumn{2}{|l|}{ Hostess } & \multicolumn{4}{|c|}{278} & \multicolumn{4}{|c|}{77} \\
\hline \multicolumn{2}{|c|}{ Staff Male } & \multicolumn{4}{|c|}{61} & \multicolumn{4}{|c|}{56} \\
\hline \multicolumn{2}{|c|}{ Staff Female } & \multicolumn{4}{|c|}{47} & \multicolumn{4}{|c|}{44} \\
\hline \multicolumn{2}{|c|}{ Patients Male } & \multicolumn{4}{|c|}{127} & \multicolumn{4}{|c|}{51} \\
\hline \multicolumn{2}{|c|}{ Patients Female } & \multicolumn{4}{|c|}{125} & \multicolumn{4}{|c|}{49} \\
\hline $\begin{array}{c}\text { Model } \\
\text { Variables }\end{array}$ & Mean & $\begin{array}{c}\text { Std. } \\
\text { Deviation }\end{array}$ & $\alpha$ & 1 & 2 & 3 & 4 & 5 & 6 \\
\hline IHRM_RS & 4.33 & .538 & .76 & 1 & & & & & \\
\hline IHRM_TD & 4.16 & .533 & .79 & $.43 * *$ & 1 & & & & \\
\hline IHRM_PA & 4.43 & .490 & .49 & $.22 * *$ & $\begin{array}{c}.43^{*} \\
*\end{array}$ & 1 & & & \\
\hline IHRM_IC & 4.46 & .412 & .51 & $.23 * *$ & $\begin{array}{c}.42 * \\
*\end{array}$ & $.43 * *$ & 1 & & \\
\hline IHRM_R & 4.43 & .420 & .60 & $.47 * *$ & $\begin{array}{c}.33^{*} \\
*\end{array}$ & $.45^{* *}$ & $.49 * *$ & 1 & \\
\hline IHRM_D & 4.18 & .695 & .71 & $.38 * *$ & $\begin{array}{l}.59 * \\
*\end{array}$ & $.48 * *$ & $.48^{* *}$ & $.49 * *$ & 1 \\
\hline Attitude & 3.06 & .765 & .96 & 1 & & & & & \\
\hline Behaviour & 3.16 & .824 & .98 & $.94 *$ & 1 & & & & \\
\hline Expertise & 3.06 & .763 & .91 & $.95^{*}$ & $.93 *$ & 1 & & & \\
\hline Waiting/Time & 3.11 & .787 & .98 & $.91 *$ & $.93 *$ & $.89 *$ & 1 & & \\
\hline Tangibles & 3.41 & 1.01 & .99 & $.95^{*}$ & $.91 *$ & $.95 *$ & $.94 *$ & 1 & \\
\hline Valence & 3.01 & .746 & .99 & $.92 *$ & $.85^{*}$ & $.93 *$ & $.89 *$ & $.94 *$ & 1 \\
\hline $\begin{array}{c}\text { Overall_Qualit } \\
\mathrm{y}\end{array}$ & 2.96 & .825 & .97 & $.82 *$ & $.69 *$ & $.84^{*}$ & $.69 *$ & $.80^{*}$ & $.91 *$ \\
\hline
\end{tabular}


International Journal of Heritage, Tourism and Hospitality Vol. (12), No. (3/2) Special issue on papers of the $11^{\text {th }}$ ICTH (2018) organized by Faculty of Tourism and Hotels, Fayoum University

\begin{tabular}{|c|c|c|c|c|c|c|c|c|c|}
\hline Staff_PQ & 4.37 & .585 & .85 & 1 & & & & & \\
\hline Patient_PQ & 2.90 & .785 & .94 & - & 1 & & & & \\
\hline $\begin{array}{c}\text { Food_Service_ } \\
\text { Quality }\end{array}$ & 3.11 & .803 & .99 & - & .00 & 1 & & & \\
\hline $\begin{array}{c}\text { Patient_Satisfa } \\
\text { ction }\end{array}$ & 3.50 & .516 & .94 & - & .08 & $.45^{* *}$ & 1 & & \\
\hline
\end{tabular}

Note: $\alpha$ : Cronbach's Alpha Coefficient, $* *<0.01, *<0.05$.

As noticed from Table (3) Cronbach's coefficients for the first six variables of the IHRMPs ranged from 0.49 of the performance appraisal variable to 0.79 of the training and development variable. However, the remaining IHRMPs were approximately scored the same coefficients. The coefficients for the seven variables of the perceived food service quality were ranged from 0.91 to 0.99 indicating reliable model constructs. Patient satisfaction items were also highly reliable (coefficient $=0.94$ ) for the six variable items.

Despite the low level of mean scores that were ranged from 2.96 to 3.41 to the perceived food service quality of the hospital patient in one hand, and the lowest mean value of their perception of the food production quality that was 2.90. However, their correlation analysis indicated well-accepted convergent validity. These results are consistent with Ahmed et al., (2015) as the majority of the patients are not always happy with the healthcare food and service quality.

The measurement properties obtained from CFA are presented in Table (4). The multiple model fit indices were statistically accepted. Chi-Square of $267 \mathrm{df}=592.89$, GFI $=0.86, \mathrm{CFI}=0.93$ and RMSEA $=0.066$ were obtained indicating the model fits the data well. All the factor loadings ranged from 0.49 to 0.94 except three items of (Sat1, Sat2 and Sat4 ranged below the threshold value) indicating that mostly the observed variables were good reflectors of their respective latent factors. Moreover, the obtained average variance extracted was greater than 0.5 except for the perceived production quality construct (F16) 0.48 indicating that the convergent validity was extremely supported. Discriminant validity was assessed by monitoring the inter-correlation among the latent factors. The discriminant validity was also supported.

Table 4: Final measurement model properties

\begin{tabular}{|c|c|c|c|}
\hline The latent and observed items & $\begin{array}{c}\text { Standardized } \\
\text { factor loadings }\end{array}$ & AVE & Construct validity \\
\cline { 1 - 2 } 1- IHRM_RS_(F1) & \multicolumn{2}{|c|}{0.55} & 0.77 \\
\cline { 1 - 2 } RS1 & 0.88 & & \\
\hline RS2 & 0.87 & & \\
\hline RS3 & 0.91 & & \multirow{2}{*}{ TD1 dropped due to cross } \\
loading
\end{tabular}


International Journal of Heritage, Tourism and Hospitality Vol. (12), No. (3/2) Special issue on papers of the $11^{\text {th }}$ ICTH (2018) organized by Faculty of Tourism and Hotels, Fayoum University

\begin{tabular}{|c|c|c|c|}
\hline 5- IHRM_R_(F5) & & \multirow[t]{5}{*}{0.76} & \multirow{5}{*}{$\begin{array}{c}0.81 \\
\text { R5 was removed due to low } \\
\text { loading }\end{array}$} \\
\hline $\mathrm{R} 1$ & 0.87 & & \\
\hline $\mathrm{R} 2$ & 0.86 & & \\
\hline R3 & 0.50 & & \\
\hline $\mathrm{R} 4$ & 0.60 & & \\
\hline 6-IHRM_D_(F6) & & \multirow[t]{5}{*}{0.73} & \multirow[t]{5}{*}{0.72} \\
\hline $\mathrm{D} 1$ & 0.63 & & \\
\hline D2 & 0.51 & & \\
\hline D3 & 0.70 & & \\
\hline $\mathrm{D} 4$ & 0.84 & & \\
\hline 7-Attitude_(F8) & & \multirow[t]{4}{*}{0.80} & \multirow[t]{4}{*}{0.92} \\
\hline Att3 & 0.82 & & \\
\hline Att2 & 0.82 & & \\
\hline Att1 & 0.90 & & \\
\hline 8-Behaviour_( F9) & & \multirow[t]{4}{*}{0.69} & \multirow[t]{4}{*}{0.97} \\
\hline Beh3 & 0.92 & & \\
\hline Beh2 & 0.82 & & \\
\hline Beh1 & 0.73 & & \\
\hline 9-Expertise_(F10) & & \multirow[t]{4}{*}{0.90} & \multirow[t]{4}{*}{0.80} \\
\hline Exp3 & 0.76 & & \\
\hline Exp2 & 0.74 & & \\
\hline Exp1 & 0.65 & & \\
\hline 10-Waiting_Time_(F11) & & \multirow[t]{4}{*}{0.65} & \multirow[t]{4}{*}{0.82} \\
\hline $\mathrm{Wt} 3$ & 0.87 & & \\
\hline $\mathrm{Wt} 2$ & 0.68 & & \\
\hline $\mathrm{Wt1}$ & 0.59 & & \\
\hline 11-Tangibles_( F12) & & \multirow[t]{4}{*}{0.68} & \multirow[t]{4}{*}{0.89} \\
\hline Tan3 & 0.72 & & \\
\hline Tan2 & 0.66 & & \\
\hline Tan1 & 0.69 & & \\
\hline 12-Valence_( F13) & & \multirow[t]{4}{*}{0.81} & \multirow[t]{4}{*}{0.96} \\
\hline $\mathrm{V} 3$ & 0.94 & & \\
\hline $\mathrm{V} 2$ & 0.65 & & \\
\hline $\mathrm{V} 1$ & 0.90 & & \\
\hline 13-Overall_Quality_( F14) & & \multirow[t]{3}{*}{0.95} & \multirow[t]{3}{*}{0.99} \\
\hline OQ2 & 0.73 & & \\
\hline OQ1 & 0.69 & & \\
\hline 14-Staff_PQ_(F16) & & \multirow[t]{9}{*}{0.48} & \multirow[t]{9}{*}{0.86} \\
\hline PQ1 & 0.82 & & \\
\hline PQ2 & 0.60 & & \\
\hline PQ3 & 0.90 & & \\
\hline PQ4 & 0.91 & & \\
\hline PQ5 & 0.60 & & \\
\hline PQ6 & 0.51 & & \\
\hline PQ7 & 0.59 & & \\
\hline PQ8 & 0.50 & & \\
\hline
\end{tabular}


International Journal of Heritage, Tourism and Hospitality Vol. (12), No. (3/2) Special issue on papers of the $11^{\text {th }}$ ICTH (2018) organized by Faculty of Tourism and Hotels, Fayoum University

\begin{tabular}{|c|c|c|c|}
\hline PQ9 & 0.59 & & \\
\hline PQ10 & 0.58 & & \\
\hline PQ11 & 0.73 & & \\
\hline PQ12 & 0.88 & & \\
\hline 16-Patient_Satisfaction_(F17) & & 0.72 & 0.92 \\
\hline Sat1 & 0.36 & & \\
\hline Sat2 & 0.33 & & \\
\hline Sat3 & 0.69 & & \\
\hline Sat4 & 0.35 & & \\
\hline Sat5 & 0.49 & & \\
\hline Sat6 & 0.51 & & \\
\hline \multicolumn{4}{|c|}{$\begin{array}{l}\text { Note: AVE }=\text { Average variance extracted, Patient_PQ was partially removed from the path } \\
\text { model due to its negative variance, however it was transformed further in the SEM model } \\
\text { to a computed variable (Total_PQP) indicating both staff and patients perceptions of food } \\
\text { quality indicators. }\end{array}$} \\
\hline
\end{tabular}

\section{Hypotheses testing}

Table (5) showed SEM results which supported four hypotheses from five. First, IHRMPs and the perceived food production quality revealed that IHRMPs have a direct positive effect on food production quality. The path coefficient between them is 0.91 with a high significance P-value $(\mathrm{P}<0.001)$. This highly significant $(\mathrm{P}<0.001)$ path coefficient provides an evidence to reject the null hypothesis (no relationship exists). Second, the path coefficient between IHRMPs and the perceived service quality is 0.08 with a high significance $\mathrm{P}$-value $(\mathrm{P}<0.001)$. Third, the path coefficient between the food production quality composite factor and patient satisfaction is -0.43 with no significant value, so the null hypothesis was supported.

Figure 2: The path model, mediation and hypotheses test

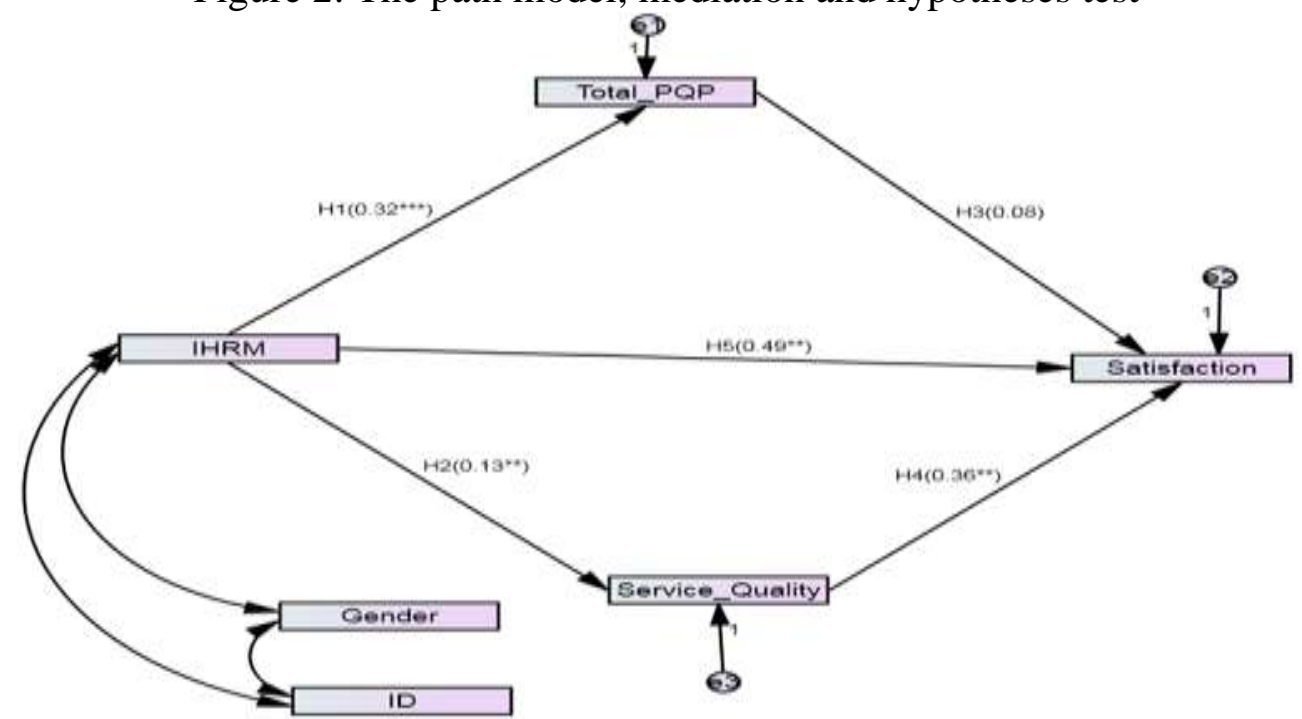

Fourth, the path coefficient between service quality and satisfaction is 0.20 with a high significance P-value $<0.001$, indicating that service quality has a positive direct effect on satisfaction. Finally, the path coefficient between IHRMPs and patient satisfaction is 0.66 with a t-value more than 1.96 to confirm that IHRMPs have a positive direct effect on patient satisfaction. SEM's test using the AMOS software was presented in Table 4 show that most of the variables have good factor loadings. The path model in Figure (2) showed first, production/service quality mediation effects between IHRMPs and patient satisfaction; second, it showed the supported hypotheses. 
International Journal of Heritage, Tourism and Hospitality Vol. (12), No. (3/2) Special issue on papers of the $11^{\text {th }}$ ICTH (2018) organized by Faculty of Tourism and Hotels, Fayoum University

Table 5: The structural model results

\begin{tabular}{|c|c|c|c|c|c|}
\hline Relationships & Std estimates & SE & t-value & P & Interpretation \\
\hline IHRM--->Total_PQP & 0.91 & 0.06 & 4.18 & $0.32^{*}$ & H1: supported \\
\hline IHRM--->Service_Quality & 0.08 & 0.05 & 4.55 & $0.13^{*}$ & H2: supported \\
\hline Total_PQP--->Satisfaction & -0.43 & 0.06 & 1.66 & 0.08 & H3: rejected \\
\hline Service_Quality---> Satisfaction & 0.20 & 0.05 & 2.76 & $0.36^{*}$ & H4: supported \\
\hline IHRM---> Satisfaction & 0.66 & 0.07 & 3.96 & $0.49^{*}$ & H5: supported \\
\hline
\end{tabular}

The model explained accepted percent of patient satisfaction variance. Finally, t-test (Table 6) was revealed no significant difference in terms of means in the two hospitals since all $t$-scores were below 1.96. Therefore, it could be concluded that there was not any variation among groups in relation to the aforementioned relationships.

Table 6: Groups mean differences test

\begin{tabular}{|c|c|c|c|c|}
\hline Variables & Case & Mean & t-value & Sig. (2-tailed) \\
\hline \multirow[t]{2}{*}{ Total_RS } & QSR & 4.2436 & -.942 & .349 \\
\hline & DAR & 4.3577 & -.815 & .421 \\
\hline \multirow[t]{2}{*}{ Total_TD } & QSR & 4.1923 & .040 & .968 \\
\hline & DAR & 4.1878 & .046 & .963 \\
\hline \multirow[t]{2}{*}{ Total_PA } & QSR & 4.4103 & -.535 & .594 \\
\hline & DAR & 4.4634 & -.476 & .637 \\
\hline \multirow[t]{2}{*}{ Total_IC } & QSR & 4.5096 & .416 & .679 \\
\hline & DAR & 4.4756 & .382 & .705 \\
\hline \multirow[t]{2}{*}{ Total_R } & QSR & 4.5412 & .427 & .670 \\
\hline & DAR & 4.5102 & .379 & .707 \\
\hline \multirow[t]{2}{*}{ Total_D } & QSR & 4.3462 & 1.250 & .214 \\
\hline & DAR & 4.1555 & 1.576 & .120 \\
\hline \multirow[t]{2}{*}{ Total_PQS } & QSR & 4.4103 & 1.235 & .219 \\
\hline & DAR & 4.3008 & 1.272 & .210 \\
\hline \multirow[t]{2}{*}{ Total_PQP } & QSR & 2.9007 & .132 & .895 \\
\hline & DAR & 2.8874 & .132 & .895 \\
\hline \multirow[t]{2}{*}{ Attitude } & QSR & 3.0716 & .334 & .739 \\
\hline & DAR & 3.0388 & .334 & .739 \\
\hline \multirow[t]{2}{*}{ Behaviour } & QSR & 3.1477 & -.287 & .774 \\
\hline & DAR & 3.1780 & -.285 & .776 \\
\hline \multirow[t]{2}{*}{ Expertise } & QSR & 3.0716 & .334 & .738 \\
\hline & DAR & 3.0388 & .334 & .738 \\
\hline \multirow[t]{2}{*}{ Waiting } & QSR & 3.0940 & -.223 & .824 \\
\hline & DAR & 3.1165 & -.224 & .823 \\
\hline \multirow[t]{2}{*}{ Tangible } & QSR & 3.4228 & .282 & .778 \\
\hline & DAR & 3.3819 & .284 & .777 \\
\hline \multirow[t]{2}{*}{ Valence } & QSR & 3.0201 & .379 & .705 \\
\hline & DAR & 2.9838 & .382 & .703 \\
\hline \multirow[t]{2}{*}{ O_Quality } & QSR & 2.9866 & .653 & .514 \\
\hline & DAR & 2.9175 & .650 & .516 \\
\hline \multirow[t]{2}{*}{ Satisfaction } & QSR & 3.5861 & 3.195 & .002 \\
\hline & DAR & 3.3786 & 3.036 & .003 \\
\hline Service_Quality & QSR & 3.1163 & .222 & .824 \\
\hline
\end{tabular}


International Journal of Heritage, Tourism and Hospitality Vol. (12), No. (3/2)

Special issue on papers of the $11^{\text {th }}$ ICTH (2018) organized by Faculty of Tourism and Hotels, Fayoum University

\begin{tabular}{|l|l|l|l|l|}
\hline & DAR & 3.0936 & .225 & .822 \\
\hline
\end{tabular}

\section{Conclusions}

This research developed and tested a conceptual framework for understanding the relationship between IHRMPs and the patient satisfaction based on the mediation effect of food production /service quality. The selected hospitals were Kasr Al-Ainy public hospital and Dar Al-Fouad private one. These two samples were selected purposively to test the research conceptual framework (Figure 1). The targeted survey respondents were patient and kitchen staff. Patients were selected to measure their service quality and satisfaction perceptions, while the kitchen employees were chosen to explore the actual usage of IHRMPs. SEM results were consistent with previous studies that patient satisfaction is determined by IHRMPs (Siddiqui and Kleiner, 1998; Amin et al., 2017). The measurement model properties and its multiple model fit indices were statistically accepted.

Results supported Four hypotheses from Five. First, the IHRMPs and the perceived food production quality revealed that IHRMPs have a direct positive effect on food production quality. Second, IHRMPs found to have a direct positive effect on the perceived service quality. Third, the relationship between food production quality and patient satisfaction was found not significant. Fourth, the path coefficient between service quality and satisfaction confirmed their positive relationship. Finally, it was found that IHRMPs has the highest effect on patient satisfaction.

The mediating effect of food service quality in the relationship between IHRMPs and patient satisfaction was supported by this empirical data to extend the previous research findings (e.g. Agarwala, 2003; Kloutsiniotis and Mihail, 2017). Unexpectedly, food production quality mediating factor was found non-significant to identify the relationship between IHRMPs and the patient satisfaction due to three prior explanations are drawn from this research: first, the low level of mean scores that was ranged from 2.90 to 3.41 to the perceived food service quality items; second the AVE low value of 0.48; third, the path coefficient between food production quality and patient satisfaction in the structural model was -0.43 . However, these contradictory results are reconciled with Hartwell et al., (2006) and Ahmed et al., (2015) as the majority of the healthcare patient are not always happy with food quality by reporting the poor food taste and being served cold.

Finally, T-test was performed to discover if there are any differences between the two selected cases. T-test result was not revealed any significant differences. Therefore, it could be concluded that there was not any variation among groups in relation to the aforementioned relationships. These results contributed much validity to the proposed conceptual model.

This research was subject to some limitations, which offer future research opportunities for other scholars. First, the study focused on two case studies in Egypt. Generalizing these results to the healthcare might be true in other Egyptian healthcare cases. However, generalizability in another region might be erroneous as participants' perceptions are totally different. Second, this research conceptual model needs more validation by conducting similar further research in other contexts. Third, the non-significant findings of this research offer future research directions. For example, food production factor was found to be not significant, suggesting future research may incorporate a number of key performance indicators for a more comprehensive investigation.

Definitely, this research contributed to the theory by providing a comprehensive measure of the IHRMPs owing to the little agreement and consensus of which is the best HRM practice models related to patient satisfaction. Another contribution was also derived from the proposed model is to identify the mediation effect of the service quality to the relationship between the IHRMPs and patient satisfaction. The managerial implications of this research highlighted the need to develop suitable food quality indicators based on patient perceptions. The need to use the comprehensive IHRMPs effectively is recommended. Future research could incorporate other service quality measure. 


\section{References}

Agarwala, T. (2003). Innovative human resource practices and organizational commitment: An empirical investigation. International Journal of Human Resource Management, 14(2), 175197.

Ahmed, M., Jones, E., Redmond, E., Hewedi, M., Wingert, A., \& Gad El Rab, M. (2015). Food production and service in UK hospitals. International Journal of Health Care Quality Assurance, 28(1), 40-54.

Aiello, T., Severt, D., Rompf, P., \& Breiter, D. (2010). A fundamental exploration of administrative views of hospital hospitality and service excellence. In Advances in Hospitality and Leisure (pp. 185-211). Emerald Group Publishing Limited. Retrieved from http://www.emeraldinsight.com/doi/abs/10.1108/S1745-3542(2010)0000006014

Amin, M., Aldakhil, A. M., Wu, C., Rezaei, S., \& Cobanoglu, C. (2017). The structural relationship between TQM, employee satisfaction and hotel performance. International Journal of Contemporary Hospitality Management, 29(4), 1256-1278. https://doi.org/10.1108/IJCHM-112015-0659

Assaf, A., Matawie, K. M., \& Blackman, D. (2008). Operational performance of health care foodservice systems. International Journal of Contemporary Hospitality Management, 20(2), 215-227.

Bhanugopan, R., Aladwan, K., \& Fish, A. (2013). A structural equation model for measuring human resource management practices in the Jordanian organisations. International Journal of Organizational Analysis, 21(4), 565-587.

Budhwar, P., \& Mellahi, K. (2007). Introduction: human resource management in the Middle East. The International Journal of Human Resource Management, 18(1), 2-10.

Blau, P. M. (1964). Exchange and power in social life. Transaction Publishers. Bloom, M., \& Milkovich, G. T. (1998). Relationships among risk, incentive pay, and organizational performance. Academy of Management Journal, 41(3), 283-297.

Byrne, B. M. (2013). Structural Equation Modeling With AMOS: Basic Concepts, Applications, and Programming, Second Edition. Routledge.

Cardello, A. V., Bell, R., \& Kramer, F. M. (1996). Attitudes of consumers toward military and other institutional foods. Food Quality and Preference, 7(1), 7-20.

Chew, J. C. L. (2004). The influence of human resource management practices on the retention of core employees of Australian organisations: An empirical study. Murdoch University. Retrieved from http://researchrepository.murdoch.edu.au/id/eprint/656

Cho, S., Woods, R. H., Jang, S. (Shawn), \& Erdem, M. (2006). Measuring the Impact of Human Resource Management Practices on Hospitality Firms' Performances. Hospitality Management, $25,262-277$.

Davis, B., Lockwood, A., Pantelidis, I., \& Alcott, P. (2013). Food and Beverage Management. Routledge.

Delery, J., \& Gupta, N. (2016). Human resource management practices and organizational effectiveness: internal fit matters. Journal of Organizational Effectiveness: People and Performance, 3(2), 139-163.

Edwards, J. S., Edwards, A., \& Salmon, J. A. (2000). Food service management in hospitals. International Journal of Contemporary Hospitality Management, 12(4), 262-266.

El-Jardali, F., Dimassi, H., Dumit, N., Jamal, D., \& Mouro, G. (2009). A national cross-sectional study on nurses' intent to leave and job satisfaction in Lebanon: implications for policy and practice. BMC Nursing, 8(1), 3. 
Farahat, T. M., Hegazy, N. N., \& Mowafy, M. (2018). Information and communication technologies in primary healthcare facilities in Egypt. Primary health care research \& development, 19(1), 88-95.

Fatima, T., Malik, S. A., \& Shabbir, A. (2018). Hospital healthcare service quality, patient satisfaction and loyalty: An investigation in context of private healthcare systems. International Journal of Quality \& Reliability Management, 35(6), 1195-1214.

Gazzoli, G., Hancer, M., \& Park, Y. (2010). The role and effect of job satisfaction and empowerment on customers' perception of service quality: a study in the restaurant industry. Journal of Hospitality \& Tourism Research, 34, 56-77.

Ghali, A. (2009). Pioneering International Standards - The Egyptian Experience (p. 110). Presented at the IFC International Health Conference, Egypt.

González-Valentín, A., Padín-López, S., \& de Ramón-Garrido, E. (2005). Patient satisfaction with nursing care in a regional university hospital in southern Spain. Journal of Nursing Care Quality, 20(1), 63-72.

Hartwell, H. J., Edwards, J. S., \& Symonds, C. (2006). Foodservice in hospital: development of a theoretical model for patient experience and satisfaction using one hospital in the UK National Health Service as a case study. Journal of Foodservice, 17(5-6), 226-238.

Haynes, P., \& Fryer, G. (2000). Human resources, service quality and performance: a case study. International Journal of Contemporary Hospitality Management, 12(4), 240-248.

Huang, C. (2017). Assessment of efficiency of manual and non-manual human resources for tourist hotel industry: An application of the hybrid DEA model. International Journal of Contemporary Hospitality Management, 29(4), 1074-1095.

Hwang, L., J., Eves, A., \& Desombre, T. (2003). Gap analysis of patient meal service perceptions. International Journal of Health Care Quality Assurance, 16(3), 143-153.

Kakuma, R., Minas, H., van Ginneken, N., Dal Poz, M. R., Desiraju, K., Morris, J. E., ... Scheffler, R. M. (2011). Human resources for mental health care: current situation and strategies for action. The Lancet, 378(9803), 1654-1663.

Kim, C. S., Spahlinger, D. A., Kin, J. M., \& Billi, J. E. (2006). Lean health care: what can hospitals learn from a world-class automaker? Journal of Hospital Medicine, 1(3), 191-199.

Kloutsiniotis, P. V., \& Mihail, D. M. (2017). Linking innovative human resource practices, employee attitudes and intention to leave in healthcare services. Employee Relations, 39(1), 34-53. https://doi.org/10.1108/ER-11-2015-0205

Koss, S. (2008). Solving the compensation puzzle: Putting together a complete pay and performance system. Society for Human Resource Management.

McEvoy, G. M., \& Buller, P. F. (2013). Human resource management practices in mid-sized enterprises. American Journal of Business, 28(1), 86-105.

Morrison, A. M. (1992). The New Leaders: Guidelines on Leadership Diversity in America. JosseyBass Management Series. ERIC.

Mostafa, M. M. (2005). An empirical study of patients' expectations and satisfactions in Egyptian hospitals. International Journal of Health Care Quality Assurance, 18(7), 516-532.

Namkung, Y., \& Jang, S. (2007). Does food quality really matter in restaurants? Its impact on customer satisfaction and behavioral intentions. Journal of Hospitality \& Tourism Research, 31(3), 387-409.

Nayeri, N. D., Nazari, A. A., Salsali, M., \& Ahmadi, F. (2005). Iranian staff nurses' views of their productivity and human resource factors improving and impeding it: a qualitative study. Human Resources for Health, 3(9), 9.

Nickson, D. (2007). Human resource management for the hospitality and tourism industries. Amsterdam: Butterworth-Heinemann. 
Porter, J., \& Cant, R. (2009). Exploring hospital patients' satisfaction with cook-chill foodservice systems: A preliminary study using a validated questionnaire. Journal of Foodservice, 20(2), 81-89.

Puckett, R. P. (2004). Food service manual for health care institutions (Vol. 127). John Wiley \& Sons.

Pulce, R. (2003). The role of human resources in health care. Nurse Leader, 1(6), 5-7.

Purcell, J., Kinnie, N., \& others. (2007). HRM and business performance. Oxford Handbook of Human Resource Management, The, 533.

Rodgers, S. (2005). Selecting a food service system: a review. International Journal of Contemporary Hospitality Management, 17(2), 147-156.

Sahin, B., Demir, C., Celik, Y., \& Teke, A. K. (2006). Factors affecting satisfaction level with the food services in a military hospital. Journal of Medical Systems, 30(5), 381-387.

Saleem, S. N., Sabri, Y. Y., \& Saeed, A. S. (2009). Radiology Education in the Faculty of Medicine at Cairo University (Kasr Al-Ainy Hospital). In Radiology Education (pp. 283-294). Springer.

Sargeant, M. N. (2010). Measuring menu performance by plate waste analysis: An evaluation of an acute care facility's spoken word liberalized menu. Clemson University.

Scotti, D. J., Harmon, J., Behson, S. J., \& Messina, D. J. (2007). Links among high-performance work environment, service quality, and customer satisfaction: An extension to the healthcare sector/practitioner application. Journal of Healthcare Management, 52(2), 109.

Severt, D., Aiello, T., Elswick, S., \& Cyr, C. (2008). Hospitality in hospitals? International Journal of Contemporary Hospitality Management, 20(6), 664-678.

Siddiqui, J., \& Kleiner, B. H. (1998). Human resource management in the health care industry. Health Manpower Management, 24(4), 143-147. https://doi.org/10.1108/09552069810215746

Smith, W. J., Upton, E., Shuster, E. J., Klein, A. J., \& Schwartz, M. L. (2004). Patient satisfaction and disease specific quality of life after uterine artery embolization. American Journal of Obstetrics and Gynecology, 190(6), 1697-1703.

Som, A. (2008). Innovative human resource management and corporate performance in the context of economic liberalization in India. The International Journal of Human Resource Management, 19(7), 1278-1297.

Tropman, J. E. (2001). The compensation solution. San Francisco: Jossey-Bass.

Tropman, J. E. (2002). The compensation solution: how to develop an employee-driven rewards system (Vol. 17). Wiley. com.

Tsaur, S.-H., \& Lin, Y.-C. (2004). Promoting service quality in tourist hotels: the role of HRM practices and service behavior. Tourism Management, 25, 471-481.

Ulrich, D. (1997). Measuring human resources: an overview of practice and a prescription for results. Human Resource Management, 36(3), 303-320.

WHO. (2010). Country cooperation strategy for WHO and Egypt 2010-2014.

Wickramasinghe, V. (2015). Effects of human resource development practices on service quality of services offshore outsourcing firms. International Journal of Quality \& Reliability Management, 32(7), 703-717.

Wolfe, R. A. (1995). Human resource management innovations: Determinants of their adoption and implementation. Human Resource Management, 34(2), 313-327.

Wright, O. R., Connelly, L. B., \& Capra, S. (2006). Consumer evaluation of hospital foodservice quality: an empirical investigation. International Journal of Health Care Quality Assurance, 19(2), 181-194. 